Sustinere

Journal of Environment and Sustainability

Volume 3 Issue 3 (2019) 186-198

Print ISSN: 2549-1245 Online ISSN: 2549-1253

Website: https://sustinerejes.com E-mail: sustinere.jes@iain-surakarta.ac.id

\title{
RESEARCH PAPER \\ Moslem women's participation in sustainable household clean water management: The case of Sekaran District
}

\author{
Annida Unnatiq Ulya* \\ ${ }^{1}$ Institut Agama Islam Negeri Surakarta, Indonesia \\ Article history: \\ Received 10 October 2019 | Accepted 23 December 2019| Available online 31 December 2019
}

\begin{abstract}
Environment is easily changing through urban development and people's growth. In this situation, the availability of clean water would be threatened unless it has a good water management. The purpose of this research is to examine Moslem women's participation in the sustainable household clean water management. This descriptive research analyses quantitative and qualitative data collected using questionnaire and interview towards 50 household women. The sampling methods employ accidental sampling in the Moslem community. This research has found that household clean water management has not been optimally done yet, so it could not perform the water use efficiency for environment and water sustainability although the women's participation rate is high $(75,40)$. In addition, the teaching of Islam has not emerged as the basic principle for water management by Moslem women in their household shown by the lack of sustainable water management practices.
\end{abstract}

Keywords: Moslem; women's participation; household water management

\section{Introduction}

UNICEF/WHO Joint Monitoring Program (JMP) in 2015 shown that community access for clean water and drinking water in developing countries had increased from 1990 to 2015, both in urban and rural areas. Indonesia in that report is one of 147 developing countries which has 'good progress' in sanitation and fulfils drinking water resources for MDGs targets. Despite that good progress, some facts show that there are still gaps between the provision of clean water, its accessibility, and distribution for years. Those gaps happen both in rural and urban areas in some regencies, including in peri-urban areas which have been developed.

Indonesia becomes the most populous single Moslem majority nation (Offenhauer, 2005). Relating to environment management, the existence of Moslem will be always correlated to the ecological system when many interactions have happened between humans and the

${ }^{*}$ Corresponding author. E-mail: annidaulya@gmail.com

DOI 10.22515/sustinere.jes.v3i3.89 
environment (Mamat et al., 2012). Moslem in Indonesia can become an agent of good deeds towards the environment with one of Islamic teaching that Moslem is a khalifah fil ardh which means that people or human beings who become a leader to managing and organizing the universe (Helmi, 2018).

Peri-urban area is defined as the city's suburbs which have appearance and combination of urban and rural characteristics (Yunus, 2008). Peri-urban areas in Semarang city have been suffered from massive land-use conversion for building and housing since 1999 to fulfil new settlement needs in relation to high-rate population growth (BPS Kota Semarang, 2015, 2016). In Semarang, the city grows to west, east, and south directions in similarly strong patterns that spread human activities to peri-urban areas (Mardiansyah et al., 2014; Pemerintah Kota Semarang, 2011, 2016). As water catchment areas have diminished, clean water supply is consequently decreased. Moreover, water is highly polluted or contaminated by household and industrial pollution which thus reduces its quality (Dinas Kesehatan Kota Semarang, 2015).

Sustainability of clean water can be afforded or guaranteed by managing water at the household level with good practices such as improving water use behaviour to reduce wastewater and use technology for water utility to reduce water losses for encouraging water efficiency. Sustainable household clean water management is aimed at making every activity using water become more efficient (UN, 2015). Besides, in order to support sustainable development programs meaning to fulfil present water needs without making any harms towards future needs, clean water management also focuses in environment conservation (Davie, 2008; Olusa et al., 2016).

Basically, households have done many efforts in water management to fulfil water for domestic needs in daily activities such as saving water in rainy season and to reduce water losses in the dry season by improving the water use behaviour (Jain et al., 2014). There is women's participation that makes big influence towards the success of water management and sanitation in household water use behaviour (Chifamba, 2013; Fisher, 2006; Nirmalawati, 2010; Nwobodo et al., 2013). Due to awareness about sustainable water, clean water management in the household level with women's participation is integrated to be one of the alternative ways to fulfil water needs without making any damages to the environment. Therefore, the author has assumed that Moslem women's participation in environmental management has much potential to bring a good sustainable clean water management starting from their households (microscale).

This research aims to examine Moslem women's participation in sustainable household clean water management in peri-urban areas in Sekaran, Semarang City. In short, research questions have delivered to seek answers about clean water management behaviour and strategies at household level and Moslem women's participation in clean water management in quantitative and qualitative matters.

\section{Literature review}

\subsection{Sustainable clean water}

The management of water resources as "efforts to plan, implement, monitor and evaluate the implementation of conservation of water resources, utilization of water resources, and control of destructive power of water" (Kodoatie \& Sjarief, 2008). Management of water 
resources is a management effort towards the water environment to maintain and increase the value of the presence of water (Davie, 2008).

The management carried out aims to protect the water environment against changes that occur by emphasizing sustainability aspects in practice (Davie, 2008; Fulazzaky, 2014; Olusa et al., 2016). The key to management of water resources is the use of water resources to meet the needs and ways to maintain these conditions.

The new paradigm in the practice of water resource management is integrated water resources management (IWRM) which involves various stakeholders at each level of water management (Davie, 2008; Elias, 2015; Fulazzaky, 2014). IWRW seeks a balance between topdown and bottom-up management. This paradigm aims to create efficiency, equity, and sustainable management of the limitations of water resources to meet needs (Fulazzaky, 2014).

\subsection{Clean water}

Clean water-based on Minister of Health Regulation Number 416 of 1990 is defined as "water used for daily needs whose quality meets health requirements and can be drunk if it has been cooked". The use of domestic water is water used in residential houses, apartments, and private residences for drinking water and other sanitation activities. The pattern of using water resources for domestic activities indicates the distribution of water use, the type of domestic water supply system, as well as the type and proportion of household water consumption (Sutikno, 1981).

The sources of clean water used in water supply for domestic purposes include rainwater, well water, and surface water (Sutikno, 1981). Rainwater is water that comes from rainfall. Well water (dug well) is groundwater that is taken from a well building. Surface water is water that is located or flowing on the surface of the ground.

In addition to the three types of clean water sources above, there are sources of clean water used by the community today, namely piped water and commercial drinking water. Piped water is water that comes from the distribution system of clean water/drinking water owned by the local government (PDAM) and the private sector, both those who have experienced water treatment and who have not yet. While commercial drinking water is mineral water distributed through the sale of water in gallons (special water bottles) by the private sector and the public. Mineral water from gallons has been processed and can be directly consumed as drinking water.

\subsection{Peri-urban area}

According to Yunus (2008), peri-urban areas are defined as areas located between cities and villages identified through mixed physical appearance of urban land and rural land but are included in urban administrative areas. The appearance of urban land is characterized by the use of non-agricultural land (built-up land), while the appearance of rural land is shown by the use of agricultural land. A peri-urban area can be known spatially based on the proportion of urban land and rural land.

The peri-urban area always undergoes transformation or changes in abiotic (physical), biotic and social environments (Yunus, 2008). Changes in the biophysical environment are indicated by the change in the form of non-urban (agrarian) land use to urban land. Changes are 
caused by increasing land requirements for settlements and built-up land not for other settlements along with the increasing population in the region. Changes in social characteristics into urban characteristics occur along with changes in the physical environment.

The transformation of the social environment occurs with socio-economic and sociocultural characteristics. The transformation of economic activities from rural areas into cities is influenced by the increase in population both native and immigrant populations that create a variety of new economic activities. Diverse economic activities subsequently lead to other social changes such as types of livelihoods, resident skills, kinship, social institutions, social strata, and mobility to lifestyle (Yunus, 2008).

\subsection{Moslem women's participation in water management}

Moslem women are women in Islamic society (Offenhauer, 2005). Moslem women today have made rapid progress in statistically measurable aspects of life, such as education and health. Empowering women becomes one thing that government and organizational society focuses on to reduce gender inequality and increase the level of Moslem women's participation as a problem solver in many aspects of life (Dzuhayatin, 2015; Offenhauer, 2005).

Humans are one of the living organisms that are in nature and carry out activities related to the environment at large. The current environmental damage is mostly caused by human behaviour, the orientation of modern human life that tends to be materialistic and hedonistic and the human perspective or understanding of environmental systems (Kementrian Lingkungan Hidup \& Majelis Lingkungan Hidup PP Muhammadiyah, 2011).

Overcoming environmental problems requires behaviour and lifestyle changes widely and culturally in the community. This is based on an understanding of the universe and the environment that underlies human behaviour. Meanwhile, the harmony of human life with nature has been conveyed in various teachings of religions or beliefs that exist in the world (Kementrian Lingkungan Hidup \& Majelis Lingkungan Hidup PP Muhammadiyah, 2011).

Human behaviour towards nature and environment comes from morality and one's faith. On the other hand, religion, especially Islam, has a clear view of conservation and saving the environment (Kementrian Lingkungan Hidup \& Majelis Lingkungan Hidup PP Muhammadiyah, 2011). This can be the basis for the formation of environmental ethics in Indonesian society, which is a country with a majority population of Moslems.

The participation approach is one approach in the implementation of management. The participation approach is a form of human relations in management. Participation involves a direct relationship that creates a full understanding of what is being faced, useful in selecting abilities according to needs as well as building awareness and willingness to be responsible for decisions that have been made (Haynes \& Massie, 1961). In a household, the role and responsibility of women in providing water for the family is one form of participation in carrying out a management function.

Participation is a way to achieve sustainability with the main idea, which is: if the community is involved in a policy, then it will be easier to accept and support the policy (Pretty, 1995; Siraj, 2002). In addition, Neef (2008) emphasizes that participation is a fundamental 
human right, related to the objectives of equity, empowerment, and strengthening of institutions.

The participation or participation approach of the community is emphasized to start from environmental and human resources in order to bring up people's mind-sets to behave (Syahrani, 2003). In addition, community participation can be empowered through various forms of simple, concrete activities aimed at resolving problems, and can be felt by the community.

Four stages in implementing participation are the planning stage, implementation stage, utilization stage and evaluation stage (Cohen \& Uphoff, 1977). While the form and typology of society are divided into seven levels of participation namely passive/manipulative participation, participation by providing information, participation through consultation, participation for material incentives, functional participation, interactive participation, and self-participation Wazir (1999, in Arifal, 2014).

Women are the main users and play a role in carrying out water management in their daily lives. Women have knowledge of water and are able to decide on the source of water that will be used to meet household needs, how much water is needed, and how to obtain, save and use water (O'Reilly, 2014). The occurrence of a scarcity of water will have a direct impact on women because women will need more effort and time to gain access to water for household needs (Elias, 2015; Upadhyay, 2005).

Elias (2015) states that there are three types of women's roles in the water sector measured through women's involvement in integrated water resources management, namely: domestic roles, productive roles, and decision-making roles. Women predominantly carry out their roles through domestic roles related to household activities. In this type of role, women have the responsibility and main role in providing water to meet household water needs.

Sustainable use of water in a household is related to women's knowledge of water and water management practices carried out by women. As consumers, women have greater responsibility in using water appropriately and efficiently (O'Reilly, 2014). In addition, women have the power to make decisions to meet their goals and needs at the household level (Duncker, 1999) so that household water management efforts aimed at streamlining water use can be done with the participation of women as the main actor.

\section{Methods}

This paper explains a descriptive research with data analysed using quantitative and qualitative methods. This research also uses the ecological paradigm to study the location and Moslem women's participation in household clean water management at that time.

The study was held in Sekaran District for approximately 2 months chosen by considering its characteristics as a peri-urban area in Semarang City. The sampling employed accidental sampling for Moslem women in the household. Both of these methods are intended to reduce the number of research objects because of the size of the population (household women) whose numbers are not known with certainty. 
Accidental sampling is an accidental sampling technique that bases consideration of the sample criteria set by observing the time and needs of researchers (Yunus, 2008). In this study, accidental sampling was chosen with the consideration that the sample population (Moslem women in the household) was a large population (in one district) but the exact number was unknown due to the absence of data on the number of female households in the study location which had been collected and reported by the Indonesian Badan Pusat Statistik (BPS) or authorized local government.

In addition, there are difficulties in meeting members of the population who can be selected within a limited period of research. Based on this, the researchers accidentally chose household Moslem women who met the criteria set and could be found directly so that they were expected to be able to describe the population even though it was not fully representative of the entire population. The criteria for the population or household women determined are productive adult women aged 18-64 years and are members of a household or can represent a household which all members are Islamic believers. Determination is based on data needs and limitations of time and researchers and guided by the opinion of Roscoe (1982, in Sugiyono, 2011) which states that the size of a feasible sample in a study is between 30 and 500 .

The questionnaires as data instruments that were distributed to 50 Moslem women in Sekaran District were already tested by validity and reliability tests. Household clean water management practices were analysed with the descriptive qualitative and strategic planning analysis. Meanwhile, Moslem women's participation rate was analysed with quantitative analysis using a descriptive statistical method.

\section{Results}

\subsection{Household clean water management}

Household clean water management is related to availability and accessibility of water by users, and their behaviour towards water to fulfil their needs. Main sources of water in the study location have been supplied by wells. There are also other sources such as dug well, water spring, and piping for clean water distributed by PDAM, a government water company.

Household clean water management was analysed from observations towards daily household water use behaviour. As a result, in Sekaran District, water needs in one household is 121 litre/people/day with 4 people as family members on the average. From 50 women respondents who filled the questionnaire, there were only $30 \%$ of women saving water in either dry season or wet season.

The significant result in this research is that those women in a household do save water in order to reduce money for water bill (financial reason above the environmental awareness), like one of the interviewees argued:

"Here, caused by some limits [dry season], we did save water. But what we have done generally is only to use water as necessary. We don't do specific actions to preserve the source [environment], there aren't any even thoughts to that."

Households mostly find it difficult to save water or do other clean water management practices because of availability of water itself. Although there is knowledge about the importance of saving water in daily life, that kind of management practices has not yet become 
necessary as households' main priority. As for it, below is one of the example statements from interviewees:

"We suppose to save [water], but considering there are many dug and artesian wells which are owned by households, and there is a [public] water spring here, so those water resources are likely to become a thing from us and for us [local people] and we use it as long as we like... [we know] saving and using water carefully is important, but people rarely think and act like that..."

This research also analyses strategic planning based on 4 dimensions: strength, weakness, opportunity, and threat in household clean water management practices by respondents in the location study. Strategic planning is a strategy of analysing, formulating and evaluating processes to examine the internal and external conditions objectively to reach some goals of planners (Rangkuti, 2017).

Data were collected from a questionnaire that was constructed due to planning, implementation and evaluation aspects. As a result, household clean water management practices in Moslem's households have not optimally been done that is described in Table 1 in this paper. From the table, the researcher examines 4 dimensions in strategic planning of household clean water management practices and thereby establishing a strategic planning which will give optimal benefits shown in Table 2 .

Table 1. Household clean water management in Sekaran District.

\begin{tabular}{|c|c|c|}
\hline \multirow[t]{2}{*}{ Aspect } & \multicolumn{2}{|r|}{ Household Clean Water Management } \\
\hline & Observation result & Description \\
\hline Planning & $\begin{array}{l}\text { Only } 26 \% \text { from } 50 \\
\text { respondents have done } \\
\text { the planning works to } \\
\text { manage clean water in } \\
\text { their household }\end{array}$ & $\begin{array}{l}\text { 1. The planning terms for managing clean water use } \\
\text { behaviour have not been a priority yet. } \\
2 \text {. The clean water management planning has only } \\
\text { been done in the dry season. } \\
\text { 3. The clean water management is planned to gain } \\
\text { the short-term goals meant to reduce the water bill } \\
\text { and save the money. }\end{array}$ \\
\hline $\begin{array}{l}\text { Implementati } \\
\text { on and } \\
\text { Evaluation }\end{array}$ & $\begin{array}{l}\text { Low practices for the } \\
\text { sustainability of clean } \\
\text { water management in } \\
\text { the household. Besides, } \\
\text { only } 17 \% \text { from } 50 \\
\text { respondents have done } \\
\text { the evaluation works to } \\
\text { manage clean water in } \\
\text { their household. }\end{array}$ & $\begin{array}{l}\text { 1. The management of clean water has not been } \\
\text { done with sustainability. Only } 30 \% \text { of respondents } \\
\text { have done saving water, while the other } \\
\text { respondents have used water without any } \\
\text { management efforts. } \\
2 \text {. There are } 70 \% \text { households of respondents } \\
\text { owning water-saving facilities such as water tank } \\
\text { and rainwater tank. From that number, there are } \\
22 \% \text { of respondents who have done saving water in } \\
\text { the dry season, and there are } 4 \% \text { of respondents } \\
\text { who have done saving water in the wet season. } \\
\text { 3. The evaluation works have not been done } \\
\text { continuously for managing daily water needs and } \\
\text { water use behaviour. }\end{array}$ \\
\hline
\end{tabular}


Table 2. Household clean water management strategy: Strategic Planning

Strength - Opportunity

1. Optimally the participation of women in households by empowering women.

2. Preserving sustainable household clean water resources.
Weakness - Opportunity

1. Managing clean water in households together with family works.

2. Government assistance for educating and empowering households.
Strength - Threat

1. Optimally the participation of women in households by encouraging environmental conservation awareness.

2. Strengthening the environmental conservation programs on sustainable water resources.

3. Intensifying the household clean water use behaviour effectively.

\subsection{Women's participation}

Women's participation rate was determined by analysing qualitative data to quantitative data with a descriptive statistical method to find the rate of participation. There are 3 categories of participation based on the value of Mean (M) and Standard deviation (SD), and the average total score from the questionnaire. The value of Mean (M) and Standard deviation (SD) were determined by the minimum and the maximum score from multiplication between the total question numbers with the weight value for each answer.

There are 19 questions with the term of weight value: 1 point for the lowest, and 5 points for the highest. The results are shown in Table 3 and Table 4 in this paper examining that category of women's participation in the study location is in a high rate of participation. The high rate of participation means that women have realized on their abilities and potential of role to participate in household clean water management practices.

Table 3. Mean and standard deviation results

\begin{tabular}{llllll}
\hline $\begin{array}{l}\text { Location } \\
\text { (district) }\end{array}$ & $\begin{array}{l}\text { Total } \\
\text { respondents }\end{array}$ & $\begin{array}{l}\text { Maximum } \\
\text { score }\end{array}$ & $\begin{array}{l}\text { Minimum } \\
\text { score }\end{array}$ & $\begin{array}{l}\text { Mean } \\
(\mathrm{M})\end{array}$ & $\begin{array}{l}\text { Standard } \\
\text { deviation (SD) }\end{array}$ \\
\hline Sekaran & 50 & 95.00 & 19.00 & 57.00 & 12.67 \\
\hline
\end{tabular}

Table 4. Household women's participation rate

\begin{tabular}{|c|c|c|c|c|}
\hline \multirow{2}{*}{$\begin{array}{l}\text { Location } \\
\text { (district) }\end{array}$} & \multirow{2}{*}{$\begin{array}{l}\text { Average } \\
\text { score (R) }\end{array}$} & \multicolumn{3}{|c|}{ Category of participation rate } \\
\hline & & $\begin{array}{l}\text { Low } \\
\mathrm{R}<(\mathrm{M}-\mathrm{SD})\end{array}$ & $\begin{array}{l}\text { Medium } \\
(\mathrm{M}-\mathrm{SD})<\mathrm{R}>(\mathrm{M}+\mathrm{SD})\end{array}$ & $\begin{array}{l}\text { High } \\
\mathrm{R}>(\mathrm{M}+\mathrm{SD})\end{array}$ \\
\hline Sekaran & 75.40 & $\mathrm{R}<44.33$ & $44.33<\mathrm{R}>60.67$ & $R>60.67$ \\
\hline
\end{tabular}

Participation act is defined as a collaborate direct relationship which makes a full of understanding towards the things to deal with, to select kinds of useful abilities, and to build awareness and willingness based on people's responsibility for their own decisions (Haynes \& 
Massie, 1961). On the other side, participation is a thing to reach sustainable condition with people as the main idea or main actor participating in making the decision, so they can easily accept and support the ideas (Elias, 2015). Additionally, participation act for water conservation will be highly successful when people know their goals and benefits (Davie, 2008).

By considering those theories and studies about participation, and also the result of participation rate and analysis in this research, the researcher believes that household women's participation which is known to be in high rate (75.40) has a big opportunity to effectively make the household clean water management become successful. The participation has been done by managing water use behaviour in their house and using water-saving facilities such as water tank and rainwater tank to preserve water in dry and rainy seasons (see Table 1). At this rate, household women already realize about their role to manage water because water is their house primary needs.

Human behaviour towards nature and environment comes from morality and one's faith. Islam has a clear view of conservation and saving the environment (Kementrian Lingkungan Hidup \& Majelis Lingkungan Hidup PP Muhammadiyah, 2011). One of Islamic teachings to Moslem is that human has a role to rule over nature (environment) because it is entrusted to human from God (Allah) (Kementrian Lingkungan Hidup \& Majelis Lingkungan Hidup PP Muhammadiyah, 2011; Kula, 2001). Meanwhile, the result has shown that awareness of environmental issues is likely low (see Table 1 and Table 2) and needs to improve by encouraging the quality of Moslem women's participation. One of the ways to improve the quality of participation makes the Islamic faith as the primary reason to do the clean water management practices in households for preserving the environment.

\subsection{Discussion}

This research was done by analysing Moslem women's participation and household clean water management as its focus. Planning, implementation, and evaluation aspects were chosen as a guide to collect and analyse research data in this study. Those aspects are used for either participation or management practices. There are 4 phases in participation: planning, implementation, utilization, and evaluation (Arifal, 2014). Meanwhile, planning, implementation, and evaluation become three functional aspects in management practices (Haynes \& Massie, 1961).

The household clean water management is one of water management practices in microscale. The water management is defined as management practices to conserve water while establishing the important value of water (Davie, 2008). The main idea for water management is the sign of water use behaviour in order to fulfil water needs and maintain its sustainability. In general, water management aims to preserve water to deal with environmental changes by focusing on sustainable practices (Davie, 2008; Fulazzaky, 2014; Olusa et al., 2016; Upadhyay, 2005).

Additionally, there is a new paradigm in the water management which means to make balancing states between the top-down and the bottom-up management in order to produce efficiency, equity, and sustainability towards the water resources limitedness to human needs (Fulazzaky, 2014). In this research study, the household clean water management becomes one of bottom-up kind of act in water management practices. 
Referring to the UN Report (2003), efficient water use is related to the concept and the goals of water management practices to sustain environmental and water conservation efforts. Reducing water use is one of the practical ways to do. Water use behaviour can get more efficient by using some water utilities, reducing clean water to flowering, or repairing water use behaviour which makes water loss (Kupchella \& Hyland, 1993; UN, 2003). Water management which is intended to make users use water efficiently will give benefits for users and also environment such as reducing the bills for water, maintaining the water sustainability, reducing the pollutant affections in water quality, and reducing the risk of water pollutions to the environment (UN, 2003).

At household level, women have strengths to make any decisions in order to fulfil their own needs and goals (O'Reilly, 2014), so household clean water management which aims to make water use become more efficient can be done with participation of women as the main actor. Woman is one of water users and participates in daily practices of water management. Women can dominantly use their potential in the domestic role which is related to household activities. In this type of role, women have the responsibility to make water available to fulfil all water needs in the household.

This research study intends to make Moslem women's participation in household clean water management as one of gender empowerment practices. To fulfil basic needs, participation becomes one of fundamental human right which is related to empowerment (Elias, 2015). Thus, women already get admitted to have knowledge about water and can decide what source of water which will be used and how much water will be needed for fulfilling their household needs, and also how to get, keep and use it (O’Reilly, 2014).

Household women as respondents in this research have also admitted to realize their responsibilities and have consciousness towards their role and participation in clean water management. This is proven by the high rate of their participation in the study location by managing water use behaviour in their house and using water-saving facilities (see Table 1) even though the management practice has not optimally been done because it does not become a priority for making clean water use efficient for users or environment.

On the other side, awareness towards environmental issues is likely low. Clean water conversation practices like saving and reusing water in wet or dry seasons in the study location are considerably lacking. Additionally, although Moslem women's participation has high participation rate, clean water management practices which have been done at household level cannot create water use efficiency and have not preserved water and environmental conservation with sustainability. In short, to gain any full benefits for households to users or environment, Moslem women's participation which has high rate should be accompanied by optimal and good clean water management practices.

From the result of this research, one thing that likely needs high attention is that the practice of using water with sustainability in a household also depends on women knowledge about water management issues and practices. The knowledge of Moslem women is expected to be influenced by Islamic teaching which guides the relationship between human and environment. However, the result of this study has found that the teaching of Islam has not emerged as the basic principle for water management by Moslem women. This is shown by the 
practice of water management, such as water-saving and water conservation, which are only done for saving the money and not related to their Islamic beliefs.

However, this research has a limit to only generally and descriptively analyse Moslem women's participation in household clean water management. The limitedness makes this research unable to analyse or find the correlation between the high rate of women's participation, the knowledge about Islamic teaching or beliefs, and the local environmental condition, or the correlation towards other influenced factors. Thus, it still needs another research for this matter (which researchers plan to do for the next study).

\section{Conclusion}

The purposes of this research are to examine Moslem women's participation in household clean water management in the peri-urban area, Sekaran District in Semarang City. There are 3 results as a conclusion of this descriptive research. Household clean water management has not optimally been done yet, so it could not perform water use efficiency for the environment. The teaching of Islam has also not emerged as the basic principle for water management by Moslem women. These results are shown by the practices of water management, such as water-saving and water conservation, which are only done for saving the money and not related to their Islamic beliefs.

Moslem women's participation rate towards household clean water management in Sekaran District is generally high with a score of 75.40, in quantitative matter. High participation is assumed to show the probability of the successfulness of household clean water management practices by Moslem women. Meanwhile, Moslem women's participation in qualitative matter is generally low because of the lack of sustainable water management practices.

\section{Acknowledgement}

This paper had been presented in The $3^{\text {rd }}$ International Conference of Sustainability and Innovation (ICoSI 2019) for International Symposium on Social Sciences, Humanities, Education, and Religious Studies (ISHERs) at Universitas Muhammadiyah Yogyakarta on July 30-31st, 2019.

\section{References}

Arifal, D. W. (2014). Partisipasi Masyarakat dalam Pengelolaan Sumberdaya Air Permukaan di Sub DAS Bengawan Solo Kabupaten Boyolali Bagian Selatan. Universitas Gadjah Mada.

Chifamba, E. (2013). Mainstreaming Gender in Pursuit of Millenium Development Goals in Water Resource Governance in Buhera, Zimbabwe. Russian Journal of Agriculture and Socio Economic Science, 10(22), 3 - 16.

Cohen, J. M., \& Uphoff, N. T. (1977). Rural development participation: concepts and measures for project design, implementation and evaluation. New York: Cornel University.

Davie, T. (2008). Fundamentals of Hydrology Second Editon. New York: Taylor \& Francise.

Dinas Kesehatan Kota Semarang. (2015). Profil Kesehatan Kota Semarang 2015. (H. P. S, Ed.). Semarang: Dinas Kesehatan Kota Semarang.

Duncker, L. (1999). Strategies for Empowerment of Women in Water Supply and Sanitation 
Projects (WRC Report No 817/1/99).

Dzuhayatin, S. R. (2015). Rezim Gender Muhammadiyah: Kontestasi Gender, Identitas, dan Eksistensi. Yogyakarta: Pustaka Pelajar.

Elias, F. (2015). Women's Roles in Integrated Water Resource Management: A Case Study of The Mutale Water User Association, Limpopo, South Africa. Monash University, South Africa.

Fisher, J. (2006). For her it's the big issue: putting women at the centre if water supply, sanitation and hygiene (Water, Sanitation and Hygiene: Evidence Report). Switzerland.

Fulazzaky, A. M. (2014). Challenges of Integrated Water Resources Management in Indonesia. Water, 6, 2000-2020.

Haynes, W. W., \& Massie, J. L. (1961). Management: Analysis, Concepts and Cases. USA: PrenticeHall, Inc.

Helmi, Z. (2018). Konsep Khalifah fil Ardhi dalam Perspektif Filsafat: Kajian Eksistensi Manusia sebagai Khalifah. Intizar, 24(1), 37 - 54.

Jain, M., Lim, Y., Arche-Nazario, J., \& Uriarte, M. (2014). Perceptional and Socio-Demographic Factors Associated with Household Drinking Water Management Strategies in Rural Puerto Rico. Plos ONE, 9(2), 1 - 8.

Kementrian Lingkungan Hidup, \& Majelis Lingkungan Hidup PP Muhammadiyah. (2011). Teologi Lingkungan (Etika Pengelolaan Lingkungan dalam Perspektif Islam). Jakarta: Deputi Komunikasi Lingkungan dan Pemberdayaan Masyarakat KemenLH dan Majelis Lingkungan Hidup PP Muhammadiyah.

Kodoatie, R. J., \& Sjarief, R. (2008). Pengelolaan Sumber Daya Air Terpadu. Yogyakarta: Andi Offset.

Kula, E. (2001). Islam and environmental conservation. Environmental Conservation, 28(1), 1-9.

Mamat, M. N., Mahamood, S. F., \& Ismail, I. (2012). Islamic Teaching on Behaviour-Based Environmental Attitude. Procedia - Social and Behavioral Sciences, 49, 85 - 92.

Mardiansyah, F. H., Wijayanti, M., \& Simanjuntak, L. (2014). Pertumbuhan dan Pergeseran Distribusi Spasial Penduduk di Kota Semarang. Riptek, 8(2), 23 - 40.

Neef, A. (2008). Lost in translation: The participatory imperative and local water governance in North Thailand and Southwest Germany. Water Alternatives, 1(1), 89-110.

Nirmalawati. (2010). Peran Wanita Rumah Tangga Miskin Dalam Pemanfaatan Air Bersih di Kecamatan Lore Utara. Jurnal SMARTek, 8, 231 - 240.

Nwobodo, C. E., Awgu, A. E., \& Irohible, I. J. (2013). Role of Intra-Household Water Management Practices in Transforming Water Resources Available for Agricultural Activities in Benue State, Nigeria. Journal of Agricultural Extension, 17(2), 122 - 129.

O’Reilly, K. (2014). Traditional women, modern women: Linking gender and commodification in Rajasthan, India. Geoforum, 37, 958 - 972.

Offenhauer, P. (2005). Women in Islamic Societies: A selected review of social scientific literature. 
Washington: Library of Congress.

Olusa, A., Olujimi, J., \& Okoko, E. (2016). Gender Involvement in Sustainable Water Project Management in Ibadan, Nigeria: A Physical Planning Perspective. In Proceedings of the Joint International Conference (JIC) on 21st Century Human Habitat: Issues, Sustainability and Development (pp. 1608 - 1613).

Pemerintah Kota Semarang. (2011). Peraturan Daerah Kota Semarang No 14 Tahun 2011 tentang Rencana Tata Ruang Wilayah (RTRW) Kota Semarang Tahun 2011 - 2031. Semarang: BAPPEDA.

Pemerintah Kota Semarang. (2016). Semarang Tangguh: Bergerak Bersama Menuju Semarang Tangguh (Buku Strategi Ketahanan Kota Semarang). Semarang: Pemerintah Kota Semarang.

Pretty, J. N. (1995). Participatory learning for sustainable agriculture. World Development1, 23(8), 1247-1263.

Rangkuti, F. (2017). Analisis SWOT: Teknik Membedah Kasus Bisnis (Cara Perhitungan Bobot, Rating, dan OCAI). Jakarta: Gramedia Pustaka Utama.

Siraj, M. (2002). Pro-Poor Participative Practices in Pakistan: An Analysis of Typology of Community Participation in Social Action Programs (1992-2002). In International Conference on Engaging Communities. Brisbane.

Sugiyono. (2011). Metode Penelitian Kuantitatif, Kualiatif dan Kombinasi (Mixed Methods). Bandung: Penerbit Alfabeta.

Sutikno. (1981). Pattern of Water Resources Utilization For Domestic Purpose in The Serayu River Basin. Universitas Gadjah Mada.

Syahrani. (2003). Analisis Peran Serta Masyarakat dalam Pengelolaan Air Bersih. Universitas Gadjah Mada.

UN. (2015). Sustainable Development Knowledge Platform - Sustainable development goals. Retrieved October 22, 2016, from https://sustainabledevelopment.un.org/topics/sustainabledevelopmentgoals\#

Upadhyay, B. (2005). Gendered livelihoods and multiple water use in North Gujarat. Agriculture and Human Values, 22, 411-420.

Yunus, H. S. (2008). Dinamika Wilayah Peri-Urban Determinan Masa Depan Kota. Yogyakarta: Pustaka Pelajar. 